\title{
The knowledge and behavior levels of the students taking disaster awareness training: The example of Tekirdağ province, Turkey
}

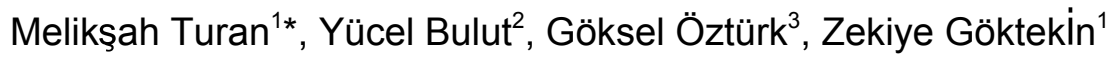 \\ ${ }^{1}$ Department of Immediate Aid and Disaster Management, Bağ larbaşı Mahallesi 29100 Gümüşhane University, Turkey \\ ${ }^{2}$ First and Immediate Aid Programme Namık Kemal University, Kampüs Caddesi 59030 Süleymanpaşa, Tekirdağ, Turkey \\ ${ }^{3}$ Department of Immediate Aid and Disaster Management, Çanakkale 18 March University, Çanakkale, Turkey
}

\begin{abstract}
The aim of this study is to determine the knowledge, skill and behavior levels of the individuals, suffering from a disaster, in terms of issues such as survival, finding a safe place, evacuation, first aid, and search and operations as of the first hours following the disaster. Within this scope, 128 students taking disaster awareness training in Vocational School of Health Services in Namık Kemal University of Turkey agreed to participate in this study. The data collection form was prepared by using the preceding studies in literature. The data were analyzed with "SPSS for Windows 15.0"' package program. Variance analysis, student's t-test, chi-square test and Pearson correlation test were performed for statistical analyses. The results in which $P$ values were $p<0.05$ were regarded as statistically meaningful. In this study, it was also analyzed whether there is a relationship between knowledge levels and behavior levels of students in operational issues of disasters or not. In the correlation analysis conducted in this regard, a very strong positive linear relationship was found between the knowledge levels and behavior levels of students $(r=0.762, p<0.001)$. Education is crucial in providing information to individuals and turning these information into behaviors. The disasters and emergency cases depend upon human behaviors. The disaster awareness trainings and the formation of desired behavior in human beings are shaped on the basis of this. The standards for disaster trainings should be set, and trainings should be provided starting from the earlier ages. Various simulation units should be utilized to improve the persistency of the training content, and trainings should be provided by disaster units. The result shows that the individuals who took disaster training were more effective in determining behavior patterns to be developed during and after disasters.
\end{abstract}

Key words: Behavior Patterns, Disaster, Disaster Awareness Level, Preparation Level

\section{Introduction}

The disasters are described as technological or human-induced events that stop or suspend life and human activities, and lead to economic and social loses (Disaster Law in Turkey, No: 5902, 2009). The country (Turkey) often faces natural disasters due to its tectonic, seismic, topographic and climatic characteristics. The human beings show response when they face with disasters for the first time and have difficulties in dealing with them. In order to minimize disaster damage, it is required to link with mitigation and preparation activities during the pre-impact phase, impact analysis, intervention, rehabilitation and reconstruction activities during the post-impact phase (Gülnerman et al., 2013). One should be prepared in order to withstand disasters.

Unfortunately, professional teams will not be sufficient for everyone during the first 72 hours (Isik et al., 2012). As the crisis phase of

\footnotetext{
*Corresponding author, email address: meliksahturan@gumushane.edu.tr
}

the disaster begins, people primarily in the exposed area, who have managed to survive, take action to save their relatives (Özkan, 2014). The crisis phase should be analyzed very well, while making preparation and planning. This tough period should cover the whole disaster potential and include all possible threats that can be faced.

Through "Awareness and Training Campaign for Disaster-Prepared Turkey" which was launched in 2013, Disaster and Emergency Management Presidency (AFAD) aims to generate families, schools, workplaces and youth, who are ready for the first 72 hours of disasters by 2017 (AFAD, 2017). It will ensure planning by learning cataclysm and dangers of the living spaces, precautions to be taken and accurate behavior patterns through raising awareness. It will be easier to cope with disasters after this plan. 
One criterion that ensures the success of disaster management plans in Turkey is to raise disaster awareness for the people. Such awareness needs to be adopted to every individual and every segment of the society (Erkal, 2009). This awareness should provide adequate attainment in terms of accurate attitude and behavior.

Karanc1 (2005) differentiates preparedness behaviors as Being Prepared (Material Stockpile), Required Knowledge and Skills, Planning, Damage Mitigation-Protective Behaviors. In this differentiation, necessary preparations for perceivable disasters should be arranged by evaluating possible and accurate results for the process before, during and after disaster. It is necessary for individuals to stock materials to maintain their vital activities, initiate various rescue activities, take security precautions and save important documents. Individuals should acquire knowledge and skills on issues such as survival, finding a safe place, evacuation, first aid, search and operations, communications, planning, disaster institutions and call signs. Specifically, they should be able to plan risk and dangers in their living spaces through protective precautions such as vulnerability, insurance and regulations. In the past, disaster awareness trainings used to cover disasters, emergency situations and plans, risk and crisis, intervention and evaluation, survival tactics after disasters, as well as short, medium and long-term sustainability of vital activities, were organized in order to reduce damages and raise awareness. As a result of trainings, for those with increased level of awareness and exercise, it is aimed to;

1. Determine preparedness knowledge level for disasters,

2. Determine preparedness behavior level for disasters,

3. Determine the correlation between preparedness knowledge and behavior levels.

\section{Materials and Methods}

This cross-sectional research was applied to the senior year students, who took disaster awareness training, at Vocational School of Health Services in Namik Kemal University. Altogether, 128 individuals agreed to participate were included in the research. The researcher itself completed the survey process by obtaining informed consent form. Necessary permissions to conduct this research were obtained before the research starts.

The data collection form was prepared by using the studies in literature. The data collection form was prepared by benefitting from the studies of Sakiroglu (2005), Ejeta et al. (2015). The survey form consists of three parts. In the first part, there are questions for descriptive socio-demographic information. In the second part, there are questions for measuring operational information levels for disaster preparedness. In the third part, there are questions for evaluating attitudes and behaviors for disaster preparedness. The data was analyzed with 'SPSS for Windows 15.0' package program. Variance analysis, student's t-test, chi- square test and Pearson correlation test were performed in statistical analyses. The results in which $P$ values are $p<0.05$ are regarded as statistically meaningful.

\section{Results and Discussion}

Altogether, 128 senior year students who took disaster awareness training at Vocational School of Health Services in Namık Kemal
University, Turkey who agreed to participate were included in the research and completed the survey form. The research group includes the senior year students who participated the disaster awareness training between 10-03-2015 and 21-03-2015. Students who participated in this research were aged between 18 and 24 . By gender, 18\% of them were men and 10.5\% were women. By education, $26.6 \%$ of students were studying Medical Documentation and Secretariat, 25.8\% were studying Medical Laboratory, 29.7\% of them were studying Child Development, and 18.1\% were studying Elderly Care Programs.

\section{The survey questions were examined under 2 sections;}

1. The correct answers for questions related to determining students' operational knowledge level about before, during and after disaster were calculated by obtaining the percentage points based on 22 correct answer. Those who answered questions correctly were given as number $(\mathrm{N})$, percentage as (\%), average point of operational knowledge as (X) and standard deviation values as (S.D.) (Table 1).

2. The correct answers about before, during and after disaster were calculated for questions related to determining students' level to apply the information they learn in disaster awareness training in real life and put them in behavior by obtaining the percentage points based on 21 correct answers. The average of the behavior level $(\mathrm{X})$ and the standard deviation values (S.D.) (Table 2).

The average points the student received from the survey of operational knowledge level are $56.05 \pm 118.85$, and from the survey of behavior level are $53.17 \pm 20.53$. Analysis of variance, Student's t test, chi-square test results are shown in Table 1 and Table 2.

The present study also analyzed whether there is a relationship between knowledge levels and behavior levels of students in operational issues of disasters. In the correlation analysis conducted in this regard, a very strong positive linear relationship was found between the knowledge levels and behavior levels of students $(\mathrm{r}=0.762, \mathrm{p}<0.001)$ (Table 3).

Lack of information and training, incorrect behaviors, unplanned development and inadequate precautions will cause more losses over time. There should be planned, systematic and realistic preparations for possible disasters in order to reduce losses. Correct and cautious behavior of individuals will increase the damages that hazard will trigger (Ministry of National Education Republic of Turkey, 2015).

Making individuals acquire information and use those in their behaviors are the success of education (Vural \& Yilmaz, 2016). Disasters and emergency situations are focused on human behaviors (Kadıoglu, 2011). The correct behaviors should be gained by individuals through disaster awareness trainings. 
Table 1 Evaluation form for operational knowledge levels for disaster preparedness

\begin{tabular}{|c|c|c|c|c|}
\hline Operational Knowledge Level & $\mathbf{N}$ & $\%$ & $\mathbf{X}$ & SD \\
\hline $\begin{array}{l}\text { 1. Do you know the simple methods that will identify the location of those who are trapped under } \\
\text { the wreckage? }\end{array}$ & 111 & 86.7 & 3.94 & 1.5502 \\
\hline 2. Do you know that secondary hazards need to be identified and suppressed? & 85 & 66.4 & 3.05 & 2.1447 \\
\hline 3. Do you know what might happen if we do not take respective protective measures during disasters? & 51 & 39.8 & 0.63 & 1.5879 \\
\hline 4. Did you learn how to turn off energy sources? & 87 & 68.0 & 3.66 & 1.8108 \\
\hline 5. Did you learn how to use the fire extinguisher? & 80 & 62.5 & 1.63 & 2.1917 \\
\hline 6. Do you know that you need to have a flash lamp, gloves and closed shoes next to your beds? & 102 & 79.7 & 2.48 & 2.2738 \\
\hline 7. Do you know that your disaster bag needs to be filled with enough water and food in advance? & 76 & 59.4 & 3.94 & 1.8108 \\
\hline 8. Did you learn First Aid practices? & 102 & 79.7 & 1.52 & 2.1574 \\
\hline 9. Do you know how to plan in your living spaces? & 55 & 43.0 & 1.42 & 2.1172 \\
\hline 10. Do you know that radio and transmitters will be used for information during and after the disaster? & 75 & 58.6 & 2.91 & 2.1917 \\
\hline 11. Do you know how to identify the hazards of your building or the structure you are in? & 84 & 65.6 & 1.81 & 2.2363 \\
\hline 12. Can you identify the exit routes in your living area? & 69 & 53.9 & 3.09 & 2.1313 \\
\hline 13. Can you identify safe spaces in your living spaces? & 71 & 55.5 & 3.44 & 1.9569 \\
\hline 14. Do you need to make backup copies of your important documents in case of their loss in disasters? & 97 & 75.8 & 2.52 & 2.2702 \\
\hline 15. Do you know where the evacuation ends? & 82 & 64.1 & 2.84 & 2.2114 \\
\hline $\begin{array}{l}\text { 16. I would try to minimize the risk for disaster victims if there are people to be saved at the first glance } \\
\text { in the wreckage. }\end{array}$ & 40 & 31.3 & 3.62 & 1.8377 \\
\hline 17. Can you identify explosives, flammable gases and liquids and corrosives? & 43 & 33.6 & 2.07 & 2.2434 \\
\hline 18. Does an exercise show the veridicality of the plans we have made? & 24 & 18.8 & 3.66 & 1.8108 \\
\hline 19. Do you know how alarm systems work? & 17 & 13.3 & 2.48 & 2.2738 \\
\hline 20. Do you know that you need to move away from hazards by making your body smaller? & 102 & 79.7 & 1.99 & 2.266 \\
\hline 21. Can you form a disaster team in living spaces? & 45 & 35.2 & 2.7 & 2.2434 \\
\hline 22. Can you help your neighbors with non-structured precautions? & 69 & 53.9 & 2.98 & 2.1695 \\
\hline
\end{tabular}

Table 2 Evaluation form for attitude and behavior in disaster preparedness

\begin{tabular}{|c|c|c|c|c|}
\hline Behavior Level & $\mathbf{N}$ & $\%$ & $\mathbf{X}$ & SD \\
\hline 1. Did you take action to get information about safe building construction and fortification? & 107 & 83.9 & 4.02 & 1.7387 \\
\hline 2. Did you identify safe zones in case of an earthquake? & 57 & 44.5 & 2.16 & 2.3838 \\
\hline 3. Did you make stock of water enough for a week and food enough for 3 days? & 114 & 89.1 & 428 & 1.4465 \\
\hline 4. Did you identify the most insecure places at home and in every room? & 61 & 47.7 & 2.31 & 2.3932 \\
\hline 5. Can you take security precautions after an earthquake? & 79 & 61.7 & 2.98 & 2.3183 \\
\hline 6. Did you identify the exit routes beforehand? & 73 & 57.0 & 2.75 & 2.3649 \\
\hline 7. Did you identify beforehand where you will meet with your family? & 34 & 26.6 & 1.26 & 2.115 \\
\hline 8. Do you secure a copy of your important documents in a waterproof bag or box at somewhere else? & 36 & 28.1 & 1.34 & 2.153 \\
\hline 9. Did you identify someone to be contacted outside of your area? & 61 & 47.7 & 2.27 & 2.3917 \\
\hline 10. Did you get a first aid kit? & 100 & 78.1 & 3.72 & 1.9796 \\
\hline 11. Did you get simple tools for light search and rescue activities? & 57 & 44.5 & 2.12 & 2.38 \\
\hline 12. Did you get a flash lamp to light up exit routes for evacuation? & 78 & 60.9 & 2.9 & 2.3363 \\
\hline 13. I get appropriate extinguishers for spaces with high risk of inflammation and explosion? & 65 & 50.8 & 2.42 & 2.394 \\
\hline 14. Did you identify responsibilities that your neighbors can take? & 102 & 79.7 & 3.83 & 1.8984 \\
\hline 15. Did you identify all risks and hazards and mark them on the map? & 27 & 21.1 & 1.04 & 1.9796 \\
\hline 16. Did you complete Earthquake Hazard Hunt at Homeand Family Disaster Preparedness Plan? & 30 & 23.4 & 1.15 & 2.0515 \\
\hline 17. Did you have exercise by preparing a scenario for a possibly affected disaster? & 37 & 28.9 & 1.41 & 2.1878 \\
\hline 18. I know where the natural gas cut-off valve is. & 49 & 38.3 & 1.86 & 2.3363 \\
\hline 19. Did you get a fire extinguisher? & 81 & 63.3 & 3.05 & 2.2977 \\
\hline 20. I can take squat-fold and protect position in wreckage. & 103 & 80.5 & 3.87 & 1.8691 \\
\hline 21. Did you fix the below mentioned big furniture on the wall in order for them not to fall in quake? & 62 & 48.4 & 2.34 & 2.394 \\
\hline
\end{tabular}


Table 3 The relationship between students' knowledge levels and behavior levels

\begin{tabular}{lccc}
\hline & & Knowledge Points & Behavior Points \\
\hline Average of operational knowledge level points & Pearson correlation & 1 & 0.762 \\
& Sig. ( & & 0.000 \\
& N & 128 & 128 \\
Average of Behavior level points & Pearson correlation & 0.762 & 1 \\
& Sig. ( & 0.000 & 128 \\
\hline
\end{tabular}

The people who are trained in disaster and emergency situations management, and the people and institutions who work in this area, is to produce the most appropriate solution for 'correct behaviors during earthquake' in the light of the obtained data as well as to transfer these to the society for reducing damages of the disaster (Marsap, 2005). The correct behavior patterns is developed by identifying and evaluating possible hazards and threats to be affected (Akgüngör, 2013).

One of the distinctive characteristics of learning spaces apart from formal education is to provide opportunities and experience that individuals cannot have in their daily lives or at school (Griffin, 1998). Disaster and emergency preparations theories and models, as well as aiming interventions by public health specialists, disaster management organizations and other actors can be the guidance.

A six year-old kindergarten student saved the lives of the entire family who are poisoned from the gas leakage from the stove in Gaziantep in 2016 (NTV). At an early age, life continues as standard education.

A continuous education is necessary for raising awareness for all segments of the society against risks and hazards in order to increase social strength and capacity against disasters. For this reason, follow-up of the behaviors of people should be well planned and scientifically observed (Akman \& Ural, 2001).

\section{Conclusion}

Disaster awareness trainings will make people learn the correct behaviors for alternative disasters to be exposed in context to Turkey and enable them to practice their learning. It is individual based, aiming to raise disaster awareness to the whole society by preparing individual member of the society. The present result shows that the individuals who participated disaster training are more effective in determining behavior patterns to be developed during and after disasters. This research further suggests that various simulation units should be utilized to improve the persistency of the training content, and trainings should be provided by individuals who are educated and willing to actively participate in intervention. Moreover, the standards for disaster trainings should be set, and trainings should be provided starting from the earlier ages.

\section{Acknowledgements}

The authors are very much thankful to Vocational School of Health Services in Namık Kemal University, for their permission to carry out this work. The contribution of participant students are highly acknowledged.

\section{References}

AFAD (Disaster and Emergency Management Presidency), (2017) https://www.afad.gov.tr/tr/2501/Afete-Hazir-TurkiyeBilinclendirme-ve-Egitim-Projesi.

Akgüngör, C. (2013). Sarsıntı Baladıgında: Kitlesel Afet Egitimi Ve Deprem Anında Birey Davranısı Örnegi, I.Ü. Siyasal Bilgiler Fakültesi Dergisi No:49. pp.29-63.

Akman N., \& Ural D. (2001). Afete Dirençli Toplum Olusturma Seferberligi, ITÜ Afet Yönetim Merkezi Yayınları, ITU Press, Istanbul.

Disaster Law in Turkey, Number 5902 (2009). http://www.mevzuat. gov.tr/MevzuatMetin/1.5.5902.pdf,.

Ejeta, L.T., Ardalan, A., \& Paton, D. (2015). Application of Behavioral Theories to Disaster and Emergency Health Preparedness: A Systematic Review. PLOS Currents Disasters.

Erkal, T., \& Degerliyurt, M. (2009). Türkiye'de Afet Yönetimi, Dogu Cografya Dergisi 22 pp.147-162.

Griffin, J. (1998). Learning Science through Practical Experiences in Museums. International Journal of Science Education, 20 (6), 655-663.

Gülnerman, A. G., Bük, O., \& Göksel, C..(2013). Afet Sonrası Kriz Yönetiminde Hayat Kurtaran Büfe Önerisi,TMMOB Cografi Bilgi Sistemleri Kongresi, Ankara.

Isı, Ö., Aydınlıglu, H.M., Koç, S., Gündogdu, O., Korkmaz, G., \& Ay, A. (2012). Afet Yönetimi ve Afet Odaklı Saglık Hizmetleri, Okmeydanı Tip Dergisi 28 (Ek sayı 2) pp.82-123.

Kadıoglu, M. (2015). Afet Yönetimi Beklenilmeyeni Beklemek, En Kötüsünü Yönetmek. T.C. Marmara Belediyeler Birligi Yayını. Yayın No: 68. Istanbul. 128-149.

Karanci, N. (2005). Afetlere Hazırlıklı Olma Davranıslarının Psikolojik Boyutlar1, 3. Istanbul ve Deprem Sempozyumu.

Marsap, A. (2005). Insan Kaynaklari Egitiminde Afet Yönetiminin Yeri: Afete Hazirlik Ve Afet Bilincinin Önemi, Deprem Sempozyumu, Kocaeli pp.1464-1467.

Ministry of National Education Republic of Turkey (2015). General Directorate of Lifelong Learning Can and Mal Security Disaster Education Modular Program.

Vural, H., \& Yilmaz, S. (2016). Determining the Knowledge and Level of Attitudes of the Secondary School Students to Environment and Nature: A Case of Erzurum.

\section{蛹TU-CDES}

